\title{
Enzymes' action on materials: Recent trends
}

\author{
Imran Khan ${ }^{\mathrm{a}}$, Jayati Ray Dutta ${ }^{\mathrm{a}, *}$ and Ramakrishnan Ganesan ${ }^{\mathrm{b}, *}$ \\ a Department of Biological Sciences, BITS Pilani, Hyderabad Campus, Jawahar Nagar, Shameerpet \\ Mandal, Hyderabad, Telangana, India \\ ${ }^{\mathrm{b}}$ Department of Chemistry, BITS Pilani, Hyderabad Campus, Jawahar Nagar, Shameerpet Mandal, \\ Hyderabad, Telangana, India
}

\begin{abstract}
In the era of increasing usage of materials, there is a growing concern of environmental aspects. This has motivated many scientists to research on greener materials and technologies. In this line, several biodegradable materials and biomolecules-based technologies have been developed in the recent years. This has triggered vivacious participation of various biomolecules such as DNA, proteins, enzymes, and cells in the field of 'materials'. Among the various biomolecules, enzymes have gained a significant position due to their applications in numerous fields including nanoparticles synthesis, polymer degradation, enzymatic lithography, biosensing and bio-fuel cells. This mini-review accounts on recent trends in selective fields such as nanoparticles synthesis, enzymatic polymer degradation and enzymatic lithography.
\end{abstract}

Keywords: Enzyme, polymer degradation, nanoparticle synthesis, enzymatic lithography

\section{Introduction}

Enzymes play a vital role in many systems due to their unique function. Enzymes are protein in nature along with a co-factor for maximum activity and are designed to carry out a specific task which is unique for each enzyme $[1,2]$. Similar to "key-lock" fit, each enzyme fits uniquely with one substrate and catalyzes the reaction [3,4]. Enzymes sourced from microorganisms or animal cell cultures bring about different substrate conversions in respective reactions. They have the ability to work as catalysts in moderate to wide range of $\mathrm{pH}$, pressure and temperature. In addition, they possess substrate specificity under appropriate environment and thus assist in manufacturing industrially critical products without any contaminations. Because of these benefits, enzymes are exploited in a variety of applications such as paper, cosmetics, food, detergent, textile and pharmaceutical industries [5-9]. Currently enzymes are also exploited as drugs [10]. Nowadays rapid progression in the enzymology is primarily the result of contemporary biotechnology's accelerated evolution over the past decades. The bulk volume of industrially exploited enzymes is hydrolyzing in action, chiefly employed for the breakdown of several natural components [11]. Enzymes with proteolytic activity are dominantly exploited in the industry, because of their ample use in the dairy and surfactant industries. Different carbohydrate breaking enzymes stand for the second largest group, mainly cellulases and amylases are been exploited in the manufacturing industries such as the starch, textile, detergent and baking industries

\footnotetext{
${ }^{*}$ Corresponding author: Jayati Ray Dutta, Department of Biological Sciences, BITS Pilani, Hyderabad Campus, Jawahar Nagar, Shameerpet Mandal, Hyderabad - 500078, Telangana, India. Tel.: +91 406630 3542; E-mail: jayati@ hyderabad.bitspilani.ac.in and Ramakrishnan Ganesan, Department of Chemistry, BITS Pilani, Hyderabad Campus, Jawahar Nagar, Shameerpet Mandal, Hyderabad - 500078, Telangana, India. Tel.: +91 406630 3602; E-mail: ram.ganesan@hyderabad.bitspilani.ac.in.
} 
[12]. Enzyme catalysis of kinetic separation and asymmetric organic molecule synthesis to extract pure molecules has also been accelerated in the recent past. They are exploited to synthesize chiral molecules during the past decade due to the greater enantioselectivity [13,14]. They are promising in the field of Green Chemistry mainly for the synthesis of chiral molecules, food additives or many drugs under the gentle eco-friendly conditions [15]. One more area where enzymes are widely exploited is bio-transformation of polymer materials. Polymer waste is extremely stable in the environment and their-biodegradability is limited. Recent reports include, the occurrence of polymer-degrading microorganisms in the environment, the isolation of new microorganisms for biodegradation, the discovery of brand-new degradation enzymes and the gene cloning for synthetic polymer-degrading enzymes [16]. One more enthralling and area of relevance for polymer degradation is "enzymatic lithography" and it is an eco-friendly approach to degrade polymer selectively and form desirable patterns that find numerous applications in biotechnology and electronics [17]. Current trends suggest the exploitation of enzymes in reduction processes for the synthesis of metal nanoparticles [18-21]. However enzyme catalysis is associated with a few problems respect to their activity and stability. These limitations can be surmounted by exploiting enzyme-reaction engineering [22]. This minireview is aimed to provide a brief perspective on the recent trends in enzyme-based technology on materials. Representative examples from the literature are discussed to present an overview on the subject.

\section{Enzymes sources and types}

Enzymes are usually obtained from animals, plants and microbes. Nevertheless, the attributes of the enzymes' origin determines the convenience, cost, and recovery process. In broad, several enzymes analogous to those of plants and animals can be obtained from microorganisms as well. There is a disposition to employ the enzymes from microbial sources for commercial purposes, since they are made abundantly by this approach [23]. The microbial enzyme industry offers rapid and robust growth of microbial sources, and thereby enables one to produce enzymes in large quantities. Microbes can be manipulated at genetic level to obtain better strains - via recombinant DNA techniques, chiefly to better the quality of the enzyme and to obtain higher yields [22].

\subsection{Enzyme production}

The enzyme industry rapidly progressed in the early 1980s and 1990s when it was established that enzymes can be obtained from the microbes. Traditionally, enzymes used to be extracted from animal and plant sources that resulted in reduced level of accessibility, swollen cost and inferior development of the enzyme industry. With the help of genetic engineering, desirable proteins are largely brought forth to satisfy the needs of enzyme industry. Therefore, to the highest degree biopharmaceuticals made nowadays are genetically modified products [46]. In recombinant synthesis, the initial step is to get the desirable DNA fragment; then the DNA is amplified and expressed in a suitable expression system. The yield, quality, production time and ease of extraction are crucial parameters for appropriate expression system for recombinant enzyme manufacturing [47]. Several enzyme expression systems have been established. These include cell cultures of bacteria, molds, mammals, yeasts, plants or insects, or via transgenic animals and plants. Various fermentation methods are employed to produce enzymes. Microbial cultures are grown on large scale fermenters for enzyme production under optimized growth conditions $[48,49]$. Solid state fermentation and submerged fermentation methods are used commonly for enzyme production, but the former one is preferred due to better maintenance of aseptic conditions and process control. 


\section{Applications}

\subsection{Enzyme mediated nanoparticle synthesis}

Synthesis of metal nanoparticles using biomolecules is attractive owing to their stability in colloidal solutions, different shapes and sizes. The broad range of nanoparticle utility is mainly due to the small size and greater surface area. A variety of synthetic approaches have been employed for metal nanoparticle synthesis [50]. However, these processes have some liabilities due to the use of harmful radiations and chemical processes. Therefore, a lot of attention has been given in the current scenario for green and sustainable synthetic approaches for nanoparticles of various sizes and shapes while preserving monodispersity. In this context, the reductive enzymes from microorganisms like bacteria and fungi have gained significant attention for the synthesis of metal nanoparticles.

Recent reports suggest the use of different reductases from Fusarium oxysporum for the synthesis of metal nanoparticles. In one such report, the extracellular Sulfate reductase from Fusarium oxysporum is employed to make cadmium sulfide nanoparticles of size 5-20 nm by the reaction of aqueous $\mathrm{CdSO}_{4}$ solution with the enzyme. The enzyme reacts and converts sulfate ions to sulfide ions, which lead to the formation of CdS nanoparticles [51]. The same group, in another study, has exploited extracellular $\alpha-\mathrm{NADPH}-d e p e n d e n t$ nitrate reductase for the synthesis of silver nanoparticles [52]. Brayner et al., has employed common cyanobacteria like Anabaena, Leptolyngbya and Clathorix to synthesize Au, $\mathrm{Pd}, \mathrm{Pt}$ and $\mathrm{Ag}$ nanoparticles of regulated size in colloidal solution protected with capping protein. They identified the intracellular protein responsible for the synthesis of nanoparticles to be a nitrogenase enzyme [53].

Silver has been used in the form of silver salts for the treatment of several bacterial infections from time immemorial. But antibiotics discovery has reduced the use of silver significantly. However, due to rapid development of nanotechnology and silver in the form of nanoparticles, did a successful return as a potent germicidal agent in the form of nanolotions and nanogels that helped reducing the use of antibiotics [55]. A pure form of alpha-amylase was used to make silver nanoparticles. The alpha-amylase reduced the silver ions resulting in the fabrication of stabilized 22-44 nm silver nanoparticles [56]. Extracellular nitrate-dependent reductase from several strains of Fusarium oxysporum was extracted and used in the production of silver nanoparticles [57]. Similarly, nitrate-dependent reductases from Aspergillus niger was shown to be capable of synthesizing silver nanoparticles. These nanoparticles were bactericidal against gram-negative Escherichia coli and gram-positive Staphylococcus aureus bacteria [58, 59]. In other developments, supernatants of Klebsiella pneumonia, Escherichia coli, and Enterobacter cloacae (Enterobacteriacae) that contain nitroreductase enzymes were used to synthesize metallic nanoparticles of silver [60]. A dimeric hydrogenase enzyme extracted from Fusarium oxysporum was employed to synthesize platinum nanoparticles [61].

Gold nanoparticles (Au NPs) possess large potential as drug carriers and also for gene delivery in gene therapy. One more unique feature of $\mathrm{Au}$ NPs is thiol group interaction, creating highly controlled means of drug or gene release [62]. Due to the surface plasmon resonance in the visible light range, Au NPs are vastly used in optical biosensors. The extract from fungi Sclerotium rolfsii containing NADPH-dependent enzyme was used by Narayanan et al., to synthesize gold nanoparticles in less than 15 minutes. They demonstrated the controllability of size and shape of nanoparticles by altering the salt and cell extract ratios [63]. Atul kumar et al., has shown that the enzyme activity was retained while synthesizing gold nanoparticles. A pure form of alpha-amylase was used to synthesize gold nanoparticles by reduction of tetrachloroaurate. The enzyme readily stabilized nanoparticles by capping in colloidal solution [64].

In other reports, in vitro biosynthesis of gold nanoparticles capped with peptide was done with help of sulfite reductase $\alpha-\mathrm{NADPH}$-dependent and phytochelatin. The enzyme sulfite reductase reduced 


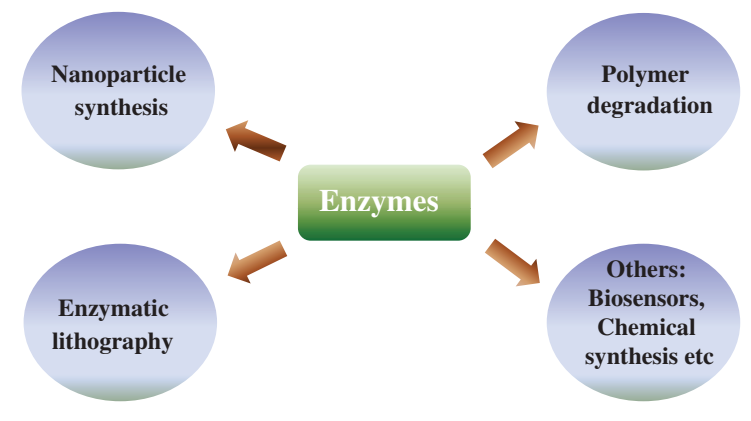

Fig. 1. Pictorial representation of various applications of enzymes.

gold ions resulting in the formation of a stable gold nanoparticle colloidal solution, with size ranging from 7-20 nm capped with the protein that stabilized the NPs in solution [65].

Rhodopseudomonas capsulata bacteria were employed for the synthesis of gold nanoparticles of different sizes and shapes. The key factor for controlling the size and shape of the gold nanoparticles was found to be the $\mathrm{pH}$ value of the reaction mixture. It was proposed that the possible mechanism liable for the reduction of $\mathrm{Au}(3+)$ to $\mathrm{Au}(0)$ that results in the fabrication of gold nanoparticles is by the secreted cofactor NADH- and NADH- dependent enzymes by the bacteria [66].

Morse et al., exploited hydrolase from marine sponge to catalyze the hydrolysis of gallium (III) nitrate that resulted in the polycondensation of gallium oxide to form nanocrystallites at low temperatures all along the length of the filaments [67].

Enzymatic synthesis of nanoparticles is highly dependent on the nature of the metal salt, enzyme and $\mathrm{pH}$ of the solution. The stability is brought about by the nature of capping proteins and interaction strength of proteins with metal nanoparticles. This may lead to varied morphologies and size control and monodispersity index.

\subsection{Enzyme lithography}

Lithography is a technique that allows one to create micro/nanostructures [70]. Traditionally photolithography is used in semiconductor industries for the fabrication of memory and circuit devices. Several advents of lithography such as dip-pen nanolithography, nanoimprint lithography, ion-beam lithography have been reported [71-73]. There is a huge interest in patterning of biomolecules as it could be beneficial for bio-sensing and tissue engineering [74-76]. However, the challenge is that biomolecules are irritable to the use of UltraVaccum, evaporation, UV irradiation, alkali or acid etching. In this backdrop, enzyme lithography has been identified as one of the suitable techniques to create micro/nanostructures at appropriate temperatures and $\mathrm{pH}$ values. This technique offers added advantages of high specificity for the substrates which is lacking in other lithographic techniques. In enzyme-lithography either the enzyme adds molecules to the substrate or etches away a part of the substrate.

One of the earliest reports on enzyme lithography was reported in 2003, in which a proteolytic enzyme was delivered onto selected locations of a thin film of bovine serum albumin (BSA). This has yielded selective etching of the BSA film on the locations where trypsin was delivered and thereby created structures at the nanoscale [77]. This was followed by further research in this area to develop techniques based on scanning probe microscope (SPM) and non-SPM based techniques [78].

Antonella Badia et al., demonstrated the enzyme lithography by employing the enzyme phospholipase A2. It catalyzes the hydrolysis of L-isomers stereoselectively, of the phospholipid bilayers made up of the 1 - and $d$ - isomers of $\alpha$-dipalmitoylphosphatidylcholine (DPPC) and 
Table 1

Some of the industrially important enzymes

\begin{tabular}{llll}
\hline Enzyme & EC number & Source & Reference \\
\hline Animal enzymes & & & \\
Rennet & 3.4 .23 .4 & Abomasum & 24 \\
Trypsin & 3.4 .21 .4 & Pancreas & 25 \\
Chymotrypsin & 3.4 .21 .1 & Pancreas & 26 \\
Lipase & 3.1 .1 .3 & Pancreas & 27 \\
Plant enzymes & & & \\
Papain & 3.4 .22 .2 & Papaya latex \\
$\alpha$-Amylase & 3.2 .1 .1 & Malted barley & 28 \\
$\beta$-Amylase & 3.2 .1 .2 & Malted barley \\
Bromelain & 3.4 .22 .4 & Pineapple latex & 29 \\
endo-1,3-Glucanase & 3.2 .1 .6 & Malted barley & 30 \\
Bacterial enzymes & & & 31 \\
$\alpha$-Amylase & 3.2 .1 .1 & Bacillus & 32 \\
$\beta$-Amylase & 3.2 .1 .2 & Bacillus & \\
Glucose isomerase & 5.3 .1 .5 & Bacillus & 33 \\
Penicillin amidase & 3.5 .1 .11 & Bacillus & 34 \\
Protease & 3.4 .21 .14 & Bacillus & 35 \\
Fungal enzymes & & & 36 \\
$\alpha$-Amylase & 3.2 .1 .1 & Aspergillus & 37 \\
Catalase & 1.11 .1 .6 & Aspergillus & \\
Cellulase & 3.2 .1 .4 & Trichoderma & 38 \\
Dextranase & 3.2 .1 .11 & Penicillium & 39 \\
Lipase & 3.1 .1 .3 & Rhizopus & Mucor miehei \\
Rennet & 3.4 .23 .6 & Aspergillus & 40 \\
Protease & 3.4 .23 .6 & Candida & 41 \\
Lipase & 3.1 .1 .3 & & 42 \\
\hline & & 43 \\
\hline
\end{tabular}

$\alpha$-dilauroylphosphatidylcholine (DLPC). The report demonstrates that the stereospecific action of enzyme can be exploited to modify polymer surface stereochemically [79].

Chow et al., has reported the use of deoxynucleotidyl transferase enzyme for enzymatic fabrication of DNA nanostructures. In their work, the capability of deoxynucleotidyl transferase to add mononucleotides at the 3' end of a short DNA (acts as an initiator) is exploited to extend a patterned self-assembled nanostructure of an oligonucleotide. Using this approach, oligonucleotide pattern having lateral dimensions in the range of 0.1 to $4 \mu \mathrm{m}$ have been shown to grow to a height up to $121 \mathrm{~nm}$ in $2 \mathrm{~h} \mathrm{[80].}$

Jinho Hyun et al., demonstrated the negative enzyme dip-pen lithography. They employed endonuclease (DNase I) to selectively remove oligonucleotides from the gold substrate functionalized with DNA [81]. Another additive based example was demonstrated for patterned growth of polyaniline conducting polymer. To achieve this, horseradish peroxidase enzyme was inked onto the tip of an Atomic Force Microscope (AFM) [82]. Controlled movement and positioning of the tip on a surface containing aniline enabled oxidative polymerization to yield polyaniline catalyzed by hydrogen peroxide, which was produced by the enzyme immobilized on the AFM tip.

Soft-lithography based enzymatic lithography also has been reported in the literature. Typically, a stamp made up of poly(dimethlylsiloxane) (PDMS) containing the desired patterns is used to ink the enzyme that would be brought into contact with a polymer film so as to deliver the enzymes 
Table 2

Representative enzymes used for the bio-synthesis of metal nanoparticles

\begin{tabular}{|c|c|c|c|c|}
\hline Enzyme & Source & Type of particle & Size (in nm) & Reference \\
\hline Sulfate reductase & Fusarium oxysporum & cadmium nanoparticles & $5-20$ & 51 \\
\hline Nitrate reductase & Fusarium oxysporum & silver nanoparticles & $10-25$ & 52 \\
\hline Nitrogenase & Anabaena flos-aquae & gold, palladium, platinum, silver & $3.5-40$ & 53 \\
\hline Nitrogenase & Leptolyngbya foveolarum & gold, palladium, platinum, silver & $3.5-40$ & 53 \\
\hline Nitrogenase & Clathorix pulvinata & gold, palladium, platinum, silver & $3.5-40$ & 53 \\
\hline Lysozyme & Hen egg white & Silver nanoparticles & $10-62$ & 54 \\
\hline$\alpha$-amylase & & silver nanoparticles & $22-44$ & 56 \\
\hline Nitrate-dependent reductase & Fusarium oxysporum & silver nanoparticles & $20-50$ & 57 \\
\hline Nitrate-dependent reductase & Aspergillus niger & silver nanoparticles & $1-20$ & 58,59 \\
\hline Nitroreductase & Klebsiella pneumonia & silver nanoparticles & $28.2-122$ & 60 \\
\hline Nitroreductase & Escherichia coli & silver nanoparticles & $28.2-122$ & 60 \\
\hline Nitroreductase & Enterobacter cloacae & silver nanoparticles & $28.2-122$ & 60 \\
\hline Hydrogenase & Fusarium oxysporum & platinum nanoparticles & $100-180$ & 61 \\
\hline NADPH-dependent reductases & Sclerotium rolfsii & gold nanoparticles & 25 & 63 \\
\hline $\begin{array}{l}\alpha \text {-NADPH-dependent } \\
\text { sulfite reductase }\end{array}$ & Fusarium oxysporum & gold nanoparticles & $7-20$ & 65 \\
\hline NADH- dependent enzymes & $\begin{array}{l}\text { Rhodopseudomonas } \\
\text { capsulata }\end{array}$ & gold nanoparticles & $10-20$ & 66 \\
\hline Hydrolase & Tethya aurantia & gallium & & 67 \\
\hline Sulfite reductase enzyme & Thermomonospora sp & gold nanoparticles & $2-6$ & 68 \\
\hline Laccase & Pleurotus ostreatus & gold nanoparticles & $22-39$ & 69 \\
\hline
\end{tabular}

onto selective locations on the polymer film. The technique is also known as microcontact printing. Enzymatic degradation of the polymer film would then lead to the information of patterns as dictated by the features from the PDMS stamp. Guyomard-Lack et al., demonstrated this approach by delivering trypsin on a poly-L-lysine (PLL) polymer using a PDMS stamp [83].

Gross et al., utilized Candida antartica lipase B (CALB) to selectively etch the poly( $\varepsilon$-caprolactone) PCL thin film (100 to $300 \mathrm{~nm}$ thickness) by delivering the enzyme on designated locations achieved by using microcontact printing as well as polymer pen lithography [85]. In a later study, the same group optimized and extended the capability of the approach to fabricate high-throughput and high-resolution pattern fabrication by using the same enzyme and polymer system. In this case, the polymer crystallinity, enzyme concentration and moisture content were found to be the major parameters that define the etch rate as well as resolution of the patterns. With these optimal conditions, they have demonstrated the patterning on a thicker PCL film $(0.1$ to $2 \mu \mathrm{m})$ with a lateral resolution of $<1 \mu \mathrm{m}$ [84].

\subsection{Polymer degradation}

Polymer degradation research has attracted attention mainly due to the increased use of the polymeric materials in various domains like agricultural industry, packaging industry, and biomedical applications. Nevertheless, increased commercial utilization of polymers has led to the waste disposal problems. In this backdrop, polymer degradation research has attracted unspoken significant attention to address the environmental issues. Enzymatic degradation of few biopolymers is presented here from recent literature along with factors that can be decisive for degradation. Microorganisms in the environment degrade polymeric materials by the action of their secreted enzymes. In biomedical applications 


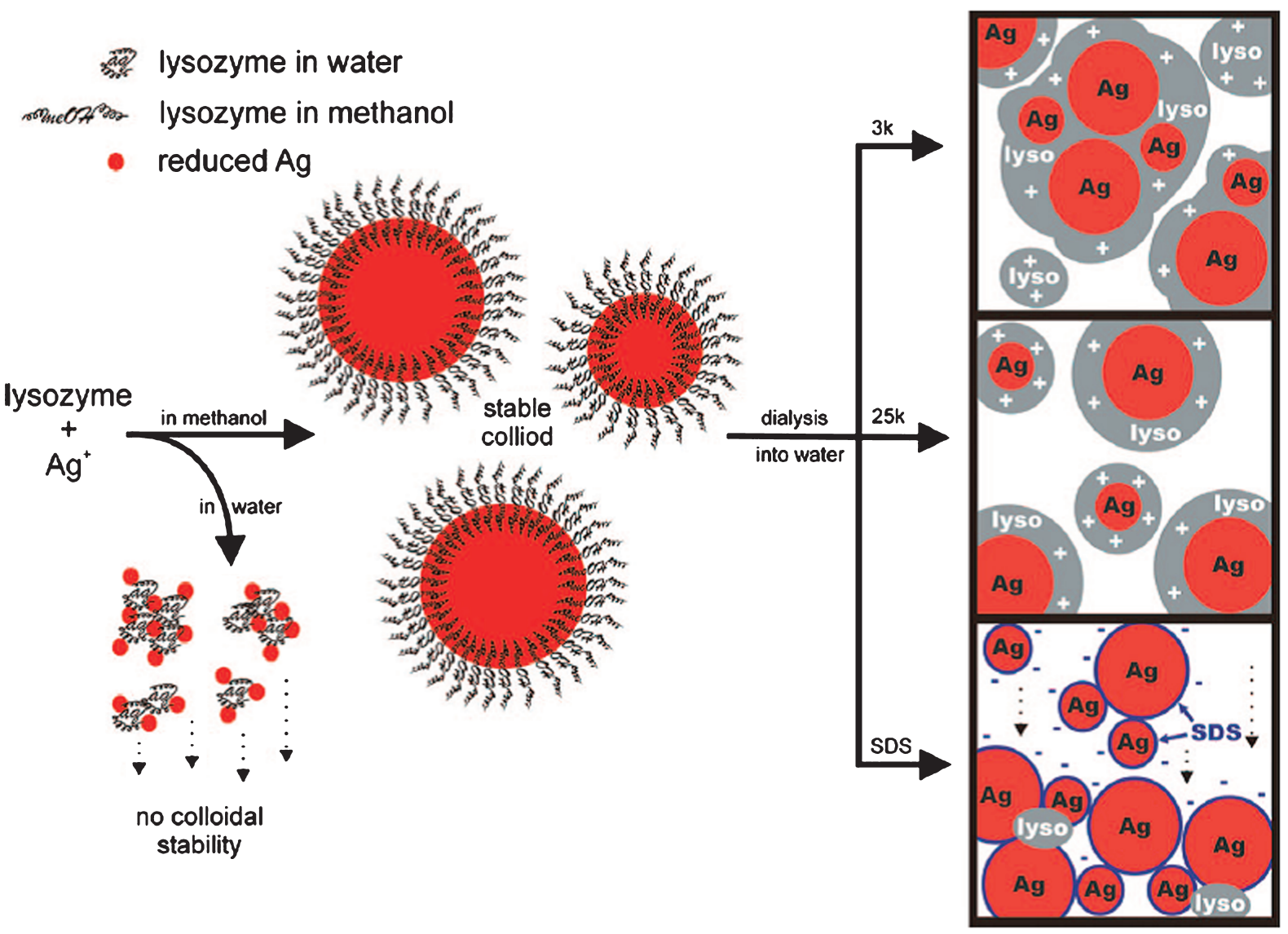

Fig. 2. Ag nanoparticle synthesis mediated by lysozyme (Reprinted with permission from [54]. Copyright (2009) American Chemical Society).

the used polymeric biomaterials may be degraded upon physical contact with body fluids and tissues by several enzymes via by oxidation or hydrolysis [86].

A study reported the radio-labeled polyester-urethanes (PU's) being degraded by cholesterol esterase, horseradish peroxidase and xanthine oxidase enzymes. It was found that the PU's were degraded faster by the action of cholesterol esterase; however the initiation of degradation was done by environmental oxidation. These in vitro studies suggested building of polymers with better degradation rates for in vivo implantation $[87,88]$. The polymer degradation rate can be altered by changing the ratio of polymer blends. A study of Pseudomonas lipase mediated PCL degradation reports 100\% weight loss for pure PCL polymer, while a blend of the same with $1 \%$ non-biodegradable polymer poly (styreneco-acrylonitrile) (SAN) degradation has yielded only 50\% weight loss. The difference in degradation pattern corresponds to the surface properties and crystal structure of the polymer blends. The enzymatic PCL degradation occurred at the amorphous surface of the polymer film. As the degradation proceeds, the content of the non-degradable component of the polymer blend increases at the surface and prevents the lipase from attacking the biodegradable PCL chains, there by stopping the polymer degradation abruptly [89].

In another similar study, degradation of poly (butylene adipate-co-butylene furandicarboxylate) (PBAFs) by porcine pancreas lipase reported that polymer degradation is influenced by the nondegradable crystalline part of the polymer. The amorphous component was degraded by the enzyme leaving the crystalline non-degradable part [90]. A study showed that the enzyme polyhydroxybu- 

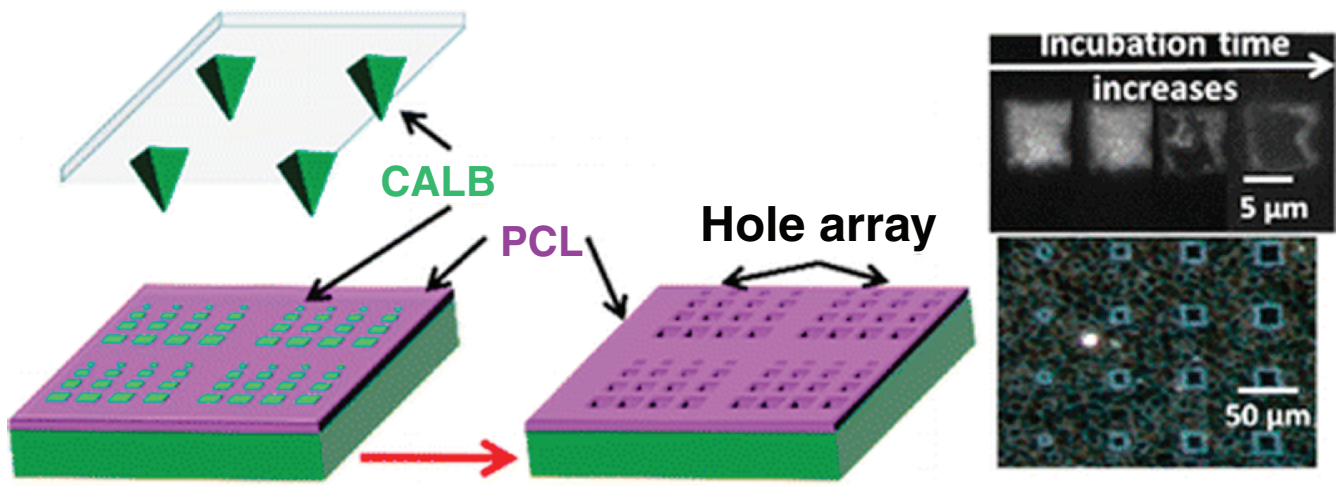

\section{Incubation}

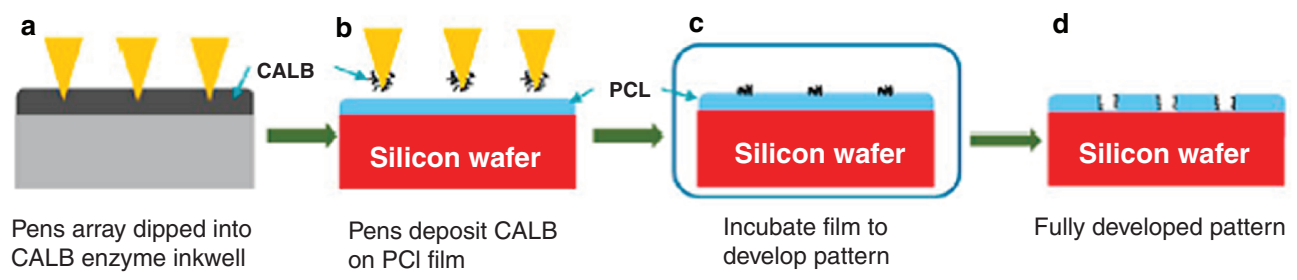

Fig. 3. Schematic representation of enzymatic lithography on PCL film (Reprinted with permission from [84]. Copyright (2009) American Chemical Society).

tyrate (PHB) depolymerase acts on polymer surface first, and then hydrolyze the amorphous part of the polymer and later the crystalline regions [91, 92]. The same was reported by Iwata et al. that enzymatic degradation is greatly influenced by the polymer subunit's crystalline nature and molecular conformation [93-95].

Reports suggest that polymer degradation by enzymes is highly dependent on reaction temperature. Degradation of cross-linked and non-crosslinked PCL polymer was done by the enzyme AK lipase in phosphate buffer saline (PBS) having $\mathrm{pH}$ 7.0. The enzymatic degradation gradually increased with increase in temperature till $55^{\circ} \mathrm{C}$ and $50^{\circ} \mathrm{C}$ for cross-linked and normal PCL, respectively. This suggests that the increased temperature increases the catalytic activity and reaches an optimum value. After attaining the optimum any further increase in temperature results in protein degradation and hydrolytic activity [96]. G. Madras et al. reported the effect of the alkyl group substitution on enzymatic and thermal degradation of poly n-(acrylates) [poly(methyl acrylate), poly(ethyl acrylate) and poly(butyl acrylate)]. Novozyme 435, lipolase and porcine pancrease were employed to degrade poly n-(acrylates) in toluene medium at various temperatures $\left(40,50\right.$ and $\left.60^{\circ} \mathrm{C}\right)$. The enzymatic degradability order at $60^{\circ} \mathrm{C}$ precedes the identical order as of thermal degradation of the respective polymers [97].

Stereo conformation of polymer subunits also determines the degradation rate of polymer by enzymes' stereospecificity. Several reports suggested the degradation of poly (L- lactide) by different enzymes like pronase, Proteinase K or lipase [98-101]. Proteinase K breaks down the ester bonds joining the L-lactyl units preferentially compared to D-lactyl units [102-105]. Starch based co-polymers were also analyzed for their biodegradability by employing different enzymes. Pullulanase, glucoamylase and $\alpha$-amylase mediated degradation of polymeric blends of corn starch with poly (ethylene-vinyl alcohol) copolymer and PCL (SEVA-C and SPCL, respectively) have been examined and reported that $\alpha$-amylase was exhibiting superior activity to the glucoamylase [106]. A study has shown the enzymatic degradation of starch-PCL 3-D scaffold by lipase and $\alpha$-amylase. It was also identified that both the enzymes were able to degrade the polymer and the polymer matrix was found to be porous in nature after the enzymatic process [107]. 
Table 3

Representative enzymes and their studies on polymer degradation

\begin{tabular}{llc}
\hline Enzyme & Polymer & Reference \\
\hline Catalase, Horse radish peroxidase, Xanthine oxidase & polyester-urethane & 87,88 \\
Lipase & $\begin{array}{l}\text { poly (butylene adipate-co-butylene } \\
\text { furandicarboxylate) (PBAFs) }\end{array}$ & 89 \\
Polyhydroxy-butyrate (PHB) depolymerase & PHB & $91-95$ \\
Lipolase, Novozyme 435, Porcine pancreas & poly n-(acrylates) & 97 \\
Pronase, lipase, Proteinase K & poly(L- lactide) & $98-105$. \\
Pullulanase, G Glucoamylase, alpha-amylase & SEVA-C, SPCL & 106,107 \\
Lipase & PCL & $88,95,107,108,109$ \\
\hline
\end{tabular}

In a relatively new approach, embedded enzymatic polymer degradation was reported by Gross et al. In this approach, an active enzyme is embedded in a polymeric matrix, which starts to degrade the whole matrix of the polymer as opposed to the conventional polymer degradation, where the degradation begins at the polymer film surface and then penetrate to the bulk. Candida antarctica Lipase B (CALB) blended with the surfactant sodium bis (2-ethylhexyl) sulfosuccinate was mixed with PCL in various proportions and casted into thin films. It was found that the PCL films containing 6.5 and $1.65 \%$ of CALB at $\mathrm{pH} 7.1$ resulted in complete degradation of the polymer in 1 and 18 days, respectively [108]. This demonstrates the ability to tune the degradation kinetics of a polymer simply by altering the enzyme loading in the matrix. In a later study, the same group has optimized flow conditions and relative humidity for the PCL degradation [109].

Thus, it is clear that the polymer degradation is influenced by the surface and nature of chemical bonds existing in the polymer. Polymer blends with various components have a significant effect in the degradation capabilities of the final material. The presence of non-degradable polymer component in polymer blends will alter the polymer films' micro-structure and thereby making it more crystalline and less accessible to the enzyme leading to lesser extent of degradation. It is evident that large number of polymers will be degraded to a great extent if proper $\mathrm{pH}$, temperature conditions along with an appropriate enzyme is provided. Further investigation and understanding of polymer degradation is required that are specific towards individual enzymes.

\section{Perspective and conclusion}

Extensive research is being carried out employing enzymes to improve the existing chemical technology and to adapt green technology. Still at large there is a considerable gap in this field which requires improvement. The use of enzymes for the synthesis of metal nanoparticles and functionalization of their surfaces is the current trend. Moreover, the metal nanoparticles synthesized were mostly spherical, irrespective of the enzyme or the capping agent used. Metal nanoparticle synthesis via enzymes is still in its infancy and vast applications are there to be explored, particularly in areas such as biosensors, targeted drug delivery, anti-microbial etc.

Enzymatic lithography is an eco-friendly approach that could yield desired biomolecular patterns without the need of toxic chemicals. This technique also offers benefits of specific recognition. This technique also is in its infancy and various enzymes could be studied for their efficiency is creating functional patterns over various substrates. Furthermore, new applications using this technique would be another area that has to be explored. Using the specific downward degradation of a polymer sheet in this technique, a polymer can be tuned either for 3-D tissue engineering scaffold or for developing nanofluidics and nano lab-on-a-chip fields. 
The use of enzymes for biodegradation of polymers has resulted in extremely efficient and rapid hydrolysis process. Extensive scrutiny has to be done to establish polymer degradation pattern to overcome waste disposal troubles associated with the plastics. Embedded enzymatic polymer degradation is another area, where huge potential is there to develop polymers of controlled biodegradability that are suitable for implant applications. In addition to the above discussed applications, enzymes are going to dominate other research areas as well like biosensors [110], stereoselective chemical synthesis [111], drug delivery [112], bio-fuel cells [113] etc. The examples discussed herein are representative. The reader is encouraged to consult various review articles that are published in these areas for more specific information [114-120].

\section{References}

[1] Glick D, King CG. The Protein Nature of Enzymes. An Investigation of Pancreatic Lipase. J Am Chem Soc 1933;55(6): 2445-9.

[2] Arnon di. Copper enzymes in isolated chloroplasts. Polyphenoloxidase in beta vulgaris. Plant Physiol 1949;24(1):1-15.

[3] Fischer E, Passmore F. Uber kohlenstoffreichere Zuckerarten aus d. Mannose. Berichte der Dtsch Chem Gesellschaft 1890;23(2):2226-39.

[4] Fischer E. Einfluss der Configuration auf die Wirkung der Enzyme. Berichte der Dtsch Chem Gesellschaft 1894;27(3): 2985-93.

[5] Schmid A, Hollmann F, Park JB, Bühler B. The use of enzymes in the chemical industry in Europe. Curr Opin Biotechnol 2002;13(4):359-66.

[6] Mateo C, Palomo JM, Fernandez-Lorente G, Guisan JM, Fernandez-Lafuente R. Improvement of enzyme activity, stability and selectivity via immobilization techniques. Enzyme Microb Technol 2007;40(6):1451-63.

[7] Martina M, Hutmacher DW. Biodegradable polymers applied in tissue engineering research: A review. Polym Int 2007;56(2):145-57.

[8] Kirk O, Borchert TV, Fuglsang CC. Industrial enzyme applications. Curr Opin Biotechnol 2002;13(4):345-51.

[9] Sheldon RA. Enzyme Immobilization: The Quest for Optimum Performance. Adv Synth Catal 2007; 349(8-9):1289307.

[10] Vellard M. The enzyme as drug: Application of enzymes as pharmaceuticals. Curr Opin Biotechnol 2003;14(4):444-50.

[11] Mohammad Badrud Duza, Dr. S A Mastan. Microbial enzymes and their applications - a review. Indo Am J Pharm Res 2013;3(8):6208-19.

[12] Ogawa J. Microbial enzymes: New industrial applications from traditional screening methods. Trends Biotechnol 1999;17(1):13-20.

[13] Koch K, Vandenberg R, Nieuwland P, Wijtmans R, Wubbolts M, Schoemaker H, Rutjes F, and Vanhest J. Enzymatic synthesis of optically pure cyanohydrins in microchannels using a crude cell lysate. Chem Eng J 2008;135S:S89-92.

[14] Teo E-L, Chuah G-K, Huguet ARJ, Jaenicke S, Pande G, Zhu Y. Process intensification with biocatalysts: Dynamic kinetic resolution and fluorous phase switch with continuous extraction. Catal Today 2004;97(4):263-70.

[15] Muñoz Solano D, Hoyos P, Hernáiz MJ, Alcántara AR, Sánchez-Montero JM. Industrial biotransformations in the synthesis of building blocks leading to enantiopure drugs. Bioresource Technol 2012;115:196-207.

[16] Premraj R, Mukesh Doble, Biodegradation of polymers. Indian J. Biotechnol 2005;4(2):186-93.

[17] Wilhelm T, Wittstock G. Generation of Periodic Enzyme Patterns by Soft Lithography and Activity Imaging by Scanning Electrochemical Microscopy. Langmuir 2002;18(24):9485-93.

[18] Crookes-Goodson WJ, Slocik JM, Naik RR. Bio-directed synthesis and assembly of nanomaterials. Chem Soc Rev 2008;37(11):2403-12.

[19] Bhattacharya D, Gupta RK. Nanotechnology and Potential of Microorganisms. Crit Rev Biotechnol 2005;25(4):199204.

[20] Durán M, Silveira CP, Durán N. Catalytic role of traditional enzymes for biosynthesis of biogenic metallic nanoparticles: A mini-review. IET Nanobiotechnol 2015;9(5):314-23.

[21] Mukherjee P, Ahmad A, Mandal D, Senapati S, Sainkar SR, Khan MI, Parishcha R, Ajaykumar P V, Alam M, Kumar R, and Sastry M. Fungus-Mediated Synthesis of Silver Nanoparticles and Their Immobilization in the Mycelial Matrix: A Novel Biological Approach to Nanoparticle Synthesis. Nano Lett 2001;1(10):515-9.

[22] Andexer JN, Langermann J V, Kragl U, Pohl M. How to overcome limitations in biotechnological processes - examples from hydroxynitrile lyase applications. Trends Biotechnol 2009;27(10):599-607. 
[23] Sabu A. Sources, Properties and Applications of Microbial Therapeutic Enzymes. Indian J Biotechnol 2003;2(3):33441.

[24] Zayas JF. Effect of Ultrasonic Treatment on the Extraction of Chymosin. J Dairy Sci Elsevier; 1986;69(7): 1767-75.

[25] Kunitz M, Northrop JH. Isolation from beef pancreas of crystalline trypsinogen, trypsin, a trypsin inhibitor, and an inhibitor-trypsin compound. J Gen Physiol 1936;19(6):991-1007.

[26] Cohen T, Gertler A, Birk Y. Pancreatic proteolytic enzymes from carp (Cyprinus carpio) - purification and physical properties of trypsin, chymotrypsin, elastase and carboxypeptidase B. Comp Biochem Physiol Part B Comp Biochem 1981;69(3):639-46.

[27] Verger R, de Haas GH, Sarda L, Desnuelle. Purification from porcine pancreas of two molecular species with lipase activity. Biochim Biophys Acta 1969;188(2):272-82.

[28] Balls AK, Lineweaver H. Isolation and properties of crystalline papain. J Biol Chem 1939;130(2):669-86.

[29] Ajandouz EH, Abe J, Svensson B, Marchis-Mouren G. Barley malt-alpha-amylase. Purification, action pattern, and subsite mapping of isozyme 1 and two members of the isozyme 2 subfamily using p-nitrophenylated maltooligosaccharide substrates. Biochim Biophys Acta 1992;1159(2):193-202.

[30] Lundgard R, Svensson B. The four major forms of barley $\beta$-amylase. Purification, characterization and structural relationship. Carlsberg Res Commun 1987;52(4):313-26.

[31] Chaurasiya RS, Umesh Hebbar H. Extraction of bromelain from pineapple core and purification by RME and precipitation methods. Sep Purif Technol 2013;111:90-7.

[32] Ballance GM, Svendsen I. Purification and amino acid sequence determination of an endo-1,3- $\beta$-glucanase from barley. Carlsberg Res Commun 1988;53(7):411-9.

[33] Mantsala P, Zalkin H. Membrane-bound and soluble extracellular alpha-amylase from Bacillus subtilis. J Biol Chem 1979;254(17):8540-7.

[34] Hensley DE, Smiley KL, Boundy JA, Lagoda AA. Beta-Amylase Production by Bacillus polymyxa on a Corn SteepStarch-Salts Medium. Appl Envir Microbiol 1980;39(3):678-80.

[35] Lama L, Nicolaus B, Calandrelli V, Romano I, Basile R, Gambacorta A. Purification and characterization of thermostable xylose(glucose) isomerase from Bacillus thermoantarcticus. J Ind Microbiol Biotechnol 2001;27(4):234-40.

[36] Chiang C, Bennett RE. Purification and Properties of Penicillin Amidase from Bacillus megaterium. J Bacteriol 1967;93(1):302-8.

[37] Beg QK, Gupta R. Purification and characterization of an oxidation-stable, thiol-dependent serine alkaline protease from Bacillus mojavensis. Enzyme Microb Technol 2003;32(2):294-304.

[38] Chang CT, Tang MS, Lin CF. Purification and properties of alpha-amylase from Aspergillus oryzae ATCC 76080. Biochem Mol Biol Int 1995;36(1):185-93.

[39] Rogalski J, Fiedurek J, Gromada A. Purification of extracellular catalase from Aspergillus niger. Acta Microbiol Pol 1998;47(1):31-43.

[40] Sternberg D. Production of cellulase by Trichoderma. Biotechnol Bioeng Symp 1976;(6):35-53.

[41] Chaiet L, Kempf AJ, Harman R, Kaczka E, Weston R, Nollstadt K, Wolf F. J. Isolation of a pure dextranase from Penicillium funiculosum. Appl Microbiol 1970;20(3):421-6.

[42] Kohno M, Kugimiya W, Hashimoto Y, Morita Y. Purification, Characterization, and Crystallization of Two Types of Lipase from Rhizopus niveus. Biosci Biotechnol Biochem, 2014.

[43] Seker S, Beyenal H, Tanyolac A. Modeling Milk Clotting Activity in the Continuous Production of Microbial Rennet from Mucor miehei. J Food Sci 1999;64(3):525-9.

[44] Malathi S, Chakraborty R. Production of Alkaline Protease by a New Aspergillus flavus Isolate under Solid-Substrate Fermentation Conditions for Use as a Depilation Agent. Appl Envir Microbiol 1991;57(3):712-6.

[45] Tan T, Zhang M, Wang B, Ying C, Deng L. Screening of high lipase producing Candida sp. and production of lipase by fermentation. Process Biochem 2003;39(4):459-65.

[46] Hodgson J. The changing bulk biocatalyst market. Biotechnology 1994;12(8):789-90.

[47] Demain AL, Vaishnav P. Production of recombinant proteins by microbes and higher organisms. Biotechnol Adv 2009;27(3):297-306.

[48] Jayati Ray Dutta P, Dutta K, Banerjee R. Optimization of culture parameters for extra-cellular protease production from a newly isolated Pseudomonas sp. using response surface and artificial neural network models. Process Biochem 2004;39(12):2193-8.

[49] Jayati Ray Dutta P, Dutta K, Banerjee R. Modeling and optimization of protease production by a newly isolated Pseudomonas sp. using a genetic algorithm. Process Biochem 2005;40(2):2879-884.

[50] Iravani S, Korbekandi H, Mirmohammadi SV, Zolfaghari B. Synthesis of silver nanoparticles: Chemical, physical and biological methods. Res Pharm Sci 2014;9(6):385-406. 
[51] Ahmad A, Mukherjee P, Mandal D, Senapati S, Khan MI, Kumar R, Sastry M. Enzyme mediated extracellular synthesis of CdS nanoparticles by the fungus, Fusarium oxysporum. J Am Chem Soc 2002;124(41):12108-09.

[52] Anil Kumar S, Abyaneh MK, Gosavi SW, Kulkarni SK, Pasricha R, Ahmad A, Khan MI. Nitrate reductase-mediated synthesis of silver nanoparticles from $\mathrm{AgNO}_{3}$. Biotechnol Lett 2007;29(3):439-45.

[53] Brayner R, Barberousse H, Hemadi M, Djedjat C, Yéprémian C, Coradin T, Livage J, Fiévet F, and Couté A. Cyanobacteria as Bioreactors for the Synthesis of $\mathrm{Au}, \mathrm{Ag}, \mathrm{Pd}$, and Pt Nanoparticles via an Enzyme-Mediated Route. J Nanosci Nanotechnol 2007;7(8):2696-708.

[54] Eby DM, Schaeublin NM, Farrington KE, Hussain SM, Johnson GR. Lysozyme catalyzes the formation of antimicrobial silver nanoparticles. ACS Nano 2009;3(4):984-94.

[55] Rai M, Yadav A, Gade A. Silver nanoparticles as a new generation of antimicrobials. Biotechnol Adv 2009;27(1):76-83.

[56] Mishra A, Sardar M. Alpha-Amylase Mediated Synthesis of Silver Nanoparticles. Sci Adv Mater 2012;4(1):143-46.

[57] Durán N, Marcato PD, Alves OL, Souza GIH De, Esposito E. Mechanistic aspects of biosynthesis of silver nanoparticles by several Fusarium oxysporum strains. J Nanobiotechnology 2005;3(1):1-7.

[58] Gaikwad S, Green Synthesis of Silver Nanoparticles Using Aspergillus niger and Its Efficacy Against Human Pathogens. Braz J Microbiol 2014;45(4):14, 1654-8.

[59] Kim JS, Kuk E, Yu KN, Kim J-H, Park SJ, Lee HJ, Kim SH, Park YK, Park YH, Hwang CY, Kim YK, Lee YS, Jeong DH, Cho MH. Antimicrobial effects of silver nanoparticles. Nanomedicine 2007;3(1):95-101.

[60] Shahverdi AR, Minaeian S, Shahverdi HR, Jamalifar H, Nohi A-A. Rapid synthesis of silver nanoparticles using culture supernatants of Enterobacteria: A novel biological approach. Process Biochem 2007;42(5):919-23.

[61] Govender Y, Riddin TL, Gericke M, Whiteley CG. On the enzymatic formation of platinum nanoparticles. J Nanoparticle Res 2009;12(1):261-71.

[62] Ghosh P, Han G, De M, Kim CK, Rotello VM. Gold nanoparticles in delivery applications. Adv Drug Deliv Rev 2008;60(11):1307-15.

[63] Narayanan KB, Sakthivel N. Facile green synthesis of gold nanostructures by NADPH-dependent enzyme from the extract of Sclerotium rolfsii. Colloids Surfaces A Physicochem Eng Asp 2011;380(1-3):156-61.

[64] Rangnekar A, Sarma TK, Singh AK, Deka J, Ramesh A, Chattopadhyay A. Retention of enzymatic activity of alphaamylase in the reductive synthesis of gold nanoparticles. Langmuir. American Chemical Society 2007;23(10):5700-6.

[65] Ku SA, Abyaneh MK, Gosavi SW, Kulkarni SK, Ahmad A, Khan MI. Sulfite reductase-mediated synthesis of gold nanoparticles capped with phytochelatin. Biotechnol Appl Biochem 2007;47(4):191-5.

[66] He S, Guo Z, Zhang Y, Zhang S, Wang J, Gu N. Biosynthesis of gold nanoparticles using the bacteria Rhodopseudomonas capsulata. Mater Lett 2007;61(18):3984-7.

[67] Kisailus D, Choi JH, Weaver JC, Yang W, Morse DE. Enzymatic Synthesis and Nanostructural Control of Gallium Oxide at Low Temperature. Adv Mater 2005;17(3):314-8.

[68] Khan SA, Ahmad A. Enzyme mediated synthesis of water-dispersible, naturally protein capped, monodispersed gold nanoparticles; their characterization and mechanistic aspects. RSC Adv 2014;4(15):7729-34.

[69] El-Batal AI, ElKenawy NM, Yassin AS, Amin MA. Laccase production by Pleurotus ostreatus and its application in synthesis of gold nanoparticles. Biotechnol Reports 2015;5:31-39.

[70] Kim J-B, Ganesan R, Choi J-H, Yun H-J, Kwon Y-G, Kim K-S, Oh TH. Photobleachable silicon-containing molecular resist for deep UV lithography. J Mater Chem 2006;16(34):3448-51.

[71] Ganesan R, Lim SH, Saifullah MSM, Hussain H, Kwok JXQ, Tse RLX, Bo HAP, Low HY. Direct nanoimprinting of metal oxides by in situ thermal co-polymerization of their methacrylates. J Mater Chem 2011;21(12):4484-92.

[72] Jang J-W, Park B, Nettikadan S. Generation of plasmonic Au nanostructures in the visible wavelength using twodimensional parallel dip-pen nanolithography. Nanoscale 2014;6(14):7912-6.

[73] Kim D-K, Ganesan R, Jung C-H, Hwang I-T, Choi J-H, Kim J-B, Nho YC, Suh DH. Micropatterning of proteins on ion beam-induced poly(acrylic acid)-grafted polyethylene film. Polym Adv Technol 2011;22(12):1989-92.

[74] Ganesan R, Kim J-B. Nonchemically amplified resists possessing cholate moiety for micropatterning of biomolecules. Microelectron Eng 2011;88(1):93-98.

[75] Yun JM, Ganesan R, Choi J-H, Kim J-B. Local pH-responsive diazoketo-functionalized photoresist for multicomponent protein patterning. ACS Appl Mater Interfaces 2013;5(20):10253-9.

[76] Ganesan R, Lee H-J, Kim J-B. Photoactive diazoketo-functionalized self-assembled monolayer for biomolecular patterning. Langmuir 2009;25(16):8888-93.

[77] Ionescu RE, Marks RS, Gheber LA. Nanolithography Using Protease Etching of Protein Surfaces. Nano Lett 2003;3(12):1639-42.

[78] Takeda S, Nakamura C, Miyamoto C, Nakamura N, Kageshima M, Tokumoto H, Miyake J. Lithographing of Biomolecules on a Substrate Surface Using an Enzyme-Immobilized AFM Tip. Nano Lett 2003;3(11):1471-4. 
[79] Moraille P, Badia A. Enzymatic lithography of phospholipid bilayer films by stereoselective hydrolysis. J Am Chem Soc 2005;127(18):6546-7.

[80] Chow DC, Lee W-K, Zauscher S, Chilkoti A. Enzymatic fabrication of DNA nanostructures: Extension of a selfassembled oligonucleotide monolayer on gold arrays. J Am Chem Soc 2005;127(41):14122-23.

[81] Hyun J, Kim J, Craig SL, Chilkoti A. Enzymatic nanolithography of a self-assembled oligonucleotide monolayer on gold. J Am Chem Soc 2004;126(15):4770-71.

[82] Luo X, Pedrosa VA, Wang J. Enzymatic nanolithography of polyaniline nanopatterns by using peroxidase-modified atomic force microscopy tips. Chem Eur J 2009;15(21):5191-4.

[83] Guyomard-Lack A, Delorme N, Moreau C, Bardeau J-F, Cathala B. Site-selective surface modification using enzymatic soft lithography. Langmuir 2011;27(12):7629-34.

[84] Mao Z, Ganesh M, Bucaro M, Smolianski I, Gross RA, Lyons AM. High throughput, high resolution enzymatic lithography process: Effect of crystallite size, moisture, and enzyme concentration. Biomacromolecules 2014;15(12):4627-36.

[85] Ganesh M, Nachman J, Mao Z, Lyons A, Rafailovich M, Gross R. Patterned enzymatic degradation of poly( $\varepsilon$ caprolactone) by high-affinity microcontact printing and polymer pen lithography. Biomacromolecules 2013;14(8): 2470-6.

[86] Ulery BD, Nair LS, Laurencin CT. Biomedical Applications of Biodegradable Polymers. J Polym Sci B Polym Phys 2011;49(12):832-64.

[87] Santerre JP, Labow RS, Duguay DG, Erfle D, Adams GA. Biodegradation evaluation of polyether and polyesterurethanes with oxidative and hydrolytic enzymes. J Biomed Mater Res 1994;28(10):1187-99.

[88] Labow RS, Meek E, Santerre JP. The biodegradation of poly(urethane)s by the esterolytic activity of serine proteases and oxidative enzyme systems. J Biomater Sci Polym Ed 1999;10(7):699-713.

[89] Cho K, Lee J, Xing P. Enzymatic degradation of blends of poly(e-caprolactone) and poly(styrene-co-acrylonitrile) by Pseudomonas lipase. J Appl Polym Sci 2002;83(4):868-79.

[90] Zhou W, Wang X, Yang B, Xu Y, Zhang W, Zhang Y, Ji J. Synthesis, physical properties and enzymatic degradation of bio-based poly(butylene adipate-co-butylene furandicarboxylate) copolyesters. Polym Degrad Stab 2013;98(11):217783.

[91] Zhang J, Kasuya K, Hikima T, Takata M, Takemura A, Iwata T. Mechanical properties, structure analysis and enzymatic degradation of uniaxially cold-drawn films of poly[(R)-3-hydroxybutyrate-co-4-hydroxybutyrate]. Polym Degrad Stab 2011;96(12):2130-8.

[92] Abe H, Doi Y, Aoki H, Akehata T. Solid-State Structures and Enzymatic Degradabilities for Melt-Crystallized Films of Copolymers of (R)-3-Hydroxybutyric Acid with Different Hydroxyalkanoic Acids. Macromolecules 1998;31(6):17917.

[93] Iwata T, Doi Y. Crystal structure and biodegradation of aliphatic polyester crystals. Macromol Chem Phys 1999;200(11):2429-42.

[94] Iwata T, Aoyagi Y, Tanaka T, Fujita M, Takeuchi A, Suzuki Y, Uesugi K. Microbeam X-ray Diffraction and Enzymatic Degradation of Poly[(R)-3-hydroxybutyrate] Fibers with Two Kinds of Molecular Conformations. Macromolecules 2006;39(17):5789-95.

[95] Numata K, Abe H, Iwata T. Biodegradability of Poly(hydroxyalkanoate) Materials. Materials 2009;2(3):1104-26.

[96] Darwis D, Mitomo H, Enjoji T, Yoshii F, Makuuchi K. Enzymatic degradation of radiation crosslinked poly ( $\varepsilon$-caprolactone). Polym Degrad Stab 1998;62(2):259-65.

[97] Mahalik JP, Madras G. Effect of the Alkyl Group Substituents on the Thermal and Enzymatic Degradation of Poly(n -alkyl acrylates). Ind Eng Chem Res 2005;44(12):4171-7.

[98] Williams DF. Enzymic hydrolysis of polylactic acid. Arch Eng Med 1971-1988 (vols 1-17) 19810;10(1):5-7.

[99] Lee SH, Song WS. Enzymatic hydrolysis of polylactic acid fiber. Appl Biochem Biotechnol 2011;164(1):89-102.

[100] Fukuzaki H, Yoshida M, Asano M, Kumakura M. Synthesis of co poly (d,l-lactic acid) with relatively low molecular weight and in vitro degradation. Eur Polym J 1989;25(10):1019-26.

[101] Mainil-Varlet P, Curtis R, Gogolewski S. Effect of in vivo and in vitro degradation on molecular and mechanical properties of various low-molecular-weight polylactides. J Biomed Mater Res 1997;36(3):360-80.

[102] Reeve MS, McCarthy SP, Downey MJ, Gross RA. Polylactide stereochemistry: Effect on enzymic degradability. Macromolecules 1994;27(3):825-31.

[103] MacDonald RT, McCarthy SP, Gross RA. Enzymatic Degradability of Poly(lactide): Effects of Chain Stereochemistry and Material Crystallinity. Macromolecules 1996;29(23):7356-61.

[104] Li S, McCarthy S. Influence of Crystallinity and Stereochemistry on the Enzymatic Degradation of Poly(lactide)s. Macromolecules 1999;32(13):4454-56. 
[105] Kikkawa Y, Abe H, Iwata T, Inoue Y, Doi Y. Crystallization, Stability, and Enzymatic Degradation of Poly(1 -lactide) Thin Film. Biomacromolecules 2002;3(2):350-6.

[106] Azevedo HS, Gama FM, Reis RL. In vitro assessment of the enzymatic degradation of several starch based biomaterials. Biomacromolecules 2003;4(6):1703-12.

[107] Duarte, Ana Rita C., João F. Mano, and Rui L. Reis. Enzymatic degradation of 3D scaffolds of starch-poly-( $\epsilon-$ caprolactone) prepared by supercritical fluid technology. Polymer Degradation and Stability 2010;95(10):2110-7.

[108] Ganesh M, Dave RN, L'Amoreaux W, Gross RA. Embedded Enzymatic Biomaterial Degradation. Macromolecules 2009;42(18):6836-9.

[109] Ganesh M, Gross RA. Embedded enzymatic biomaterial degradation: Flow conditions \& relative humidity. Polymer 2012;53(16):3454-61.

[110] Putzbach W, Ronkainen NJ. Immobilization techniques in the fabrication of nanomaterial-based electrochemical biosensors: A review. Sensors 2013;13(4):4811-40.

[111] Classen T, Korpak M, Schölzel M, Pietruszka J. Stereoselective Enzyme Cascades: An Efficient Synthesis of Chiral $\gamma$-Butyrolactones. ACS Catal 2014;4(5):1321-31.

[112] Gutowski SM, Shoemaker JT, Templeman KL, Wei Y, Latour RA, Bellamkonda RV, LaPlaca MC, García A J. Proteasedegradable PEG-maleimide coating with on-demand release of IL-1Ra to improve tissue response to neural electrodes. Biomaterials 2015;44:55-70.

[113] Willner I, Yan Y-M, Willner B, Tel-Vered R. Integrated Enzyme-Based Biofuel Cells-A Review. Fuel Cells 2009;9(1):724.

[114] O'Reilly E, Turner NJ. Enzymatic cascades for the regio- and stereoselective synthesis of chiral amines. Perspect Sci 2015;4:55-61.

[115] Gross RA, Kumar A, Kalra B. Polymer Synthesis by In Vitro Enzyme Catalysis. Chem Rev 2001;101(7):2097-124.

[116] Banerjee A, Chatterjee K, Madras G. Enzymatic degradation of polymers: A brief review. Mater Sci Technol 2014;30(5):567-73.

[117] Shah AA, Hasan F, Hameed A, Ahmed S. Biological degradation of plastics: A comprehensive review. Biotechnol Adv 2008;26(3):246-65.

[118] Zeng S, Yong K-T, Roy I, Dinh X-Q, Yu X, Luan F. A Review on Functionalized Gold Nanoparticles for Biosensing Applications. Plasmonics 2011;6(3):491-506.

[119] Thakkar KN, Mhatre SS, Parikh RY. Biological synthesis of metallic nanoparticles. Nanomedicine 2010;6(2):257-62.

[120] Ganesan R, Kratz K, Lendlein A. Multicomponent protein patterning of material surfaces. J Mater Chem 2010;20(35):7322-31. 